\title{
ETHNO-RELIGIOUS IDENTIFICATION AND SOCIAL DISTANCE BETWEEN MUSLIMS AND CHRISTIANS: Analysis on Social Identity Theory
}

\author{
CAHYO PAMUNGKAS*
}

\begin{abstract}
This article aims to investigate the relationship between ethno-religious identity and the social distance between Muslims and Christians in Ambon and Yogyakarta, taking into account factors at the individual level. Also, this research is addressed to fill a gap in the literature between studies that emphasize economic and political competition as the main sources of conflict, and studies that focus on prejudice and discrimination as causes of conflict. The central question is: "to what extent is ethno-religious identification present among Muslims and Christians in Ambon and Yogyakarta and observable in their daily lives?" This research uses social identity theory that attempts to question why people like their in-group, and dislike out-groups. The theory says that individuals struggle for positive in-group distinctiveness, and have positive attitudes toward their in-group and negative attitudes towards out-groups. This research uses both quantitative and qualitative approaches. A survey was conducted with I50o university students from six universities in Ambon and Yogyakarta. By using quantitative and qualitative methods of analysis, this study came up with several findings. Firstly, the study found high levels of religious identification among Muslim and Christian respondents, demonstrated by their participation in religious practices, which we define as frequency of praying, attending religious services, and reading the Holy Scriptures. Secondly, social distance consists of contact avoidance, avoidance of future spouses from another religion, and the support for residential segregation. Differences from the mean show that Muslim respondents tend to display higher contact avoidance and support for residential segregation compared to Christian respondents. Thirdly, analysis of variance demonstrates that elements of ethno-religious identity are related significantly to elements of social distance.
\end{abstract}

Keywords: ethno-religious identification, religious practices, cultural practices, and social distance.

\section{Abstrak}

Artikel ini mengkaji hubungan antara identitas etno-religius dan jarak sosial antara Muslim dan Kristen di Ambon dan Yogyakarta, dengan mempertimbangkan variabel indivudual. Selain itu, penelitian ini ditujukan untuk mengisi kesenjangan dalam literatur antara studi yang menekankan kontestasi ekonomi dan politik sebagai sumber utama konflik, dan studi yang berfokus pada prasangka dan diskriminasi sebagai penyebab konflik. Pertanyaan utama adalah: "? Sejauh identifikasi etnik dan agama di antara Muslim dan Kristen di Ambon dan Yogyakarta dan diamati dalam kehidupan sehari-hari mereka." Penelitian ini menggunakan teori identitas sosial yang menjelaskan mengapa kebanyakan individu lebih menyukai kelompok nya dan tidak menyukai anggota-anggota kelompok lain. . Teori ini mengatakan bahwa individu berjuang untuk mencapai citra positif kelompoknya dan memperjuangkannya. Penelitian ini menggunakan pendekatan kuantitatif dengan survei terhadap I.50o mahasiswa dari enam perguruan tinggi di Ambon dan Yogyakarta. Dengan menggunakan metode analisis kuantitatif analisis, penelitian ini memajukan beberapa temuan. Pertama, studi ini menemukan tingkat tinggi identifikasi keagamaan di kalangan responden Muslim dan Kristen, yang ditunjukkan oleh partisipasi mereka dalam praktik keagamaan seperti frekuensi berdoa, menghadiri ibadah keagamaan, dan membaca Kitab Suci. Kedua, jarak sosial terdiri dari penghindaran kontak, menghindari pasangan masa depan dari agama lain, dan dukungan untuk menetap dalam pemukiman yang tersegregasi secara agama atau etnik.. Responden Muslim cenderung menampilkan menghindari kontak lebih tinggi dan dukungan untuk menetap di pemukiman yang tersegregasi dibandingkan dengan responden Kristen. Ketiga, Analysis varians menunjukkan bahwa unsur-unsur identitas etno-religius terkait secara signifikan dengan unsur-unsur dari jarak sosial.

Kata kunci: identifikasi etno-religius, praktik keagamaan, praktek-praktek budaya, dan jarak sosial.

* Research Center for Regional Resources (PSDR), The Indonesian Institute for Sciences (LIPI), Jakarta, Indonesia. E-mail: Cahyopamungkas_lipi@yahoo.com.

Copyright (C) 2016 The Author. (C) 2016 Deputy of Social Sciences and Humanities. All rights reserved. Printed in Indonesia. Journal of Indonesian Social Sciences and Humanities (JISSH); Vol. 6, Issue I, (20I6), pp. 53-7I.

ISSN: $1979-843 I$ 


\section{INTRODUCTION}

Ethno-religious identification refers to an individual's processes of social categorization, identification and contra-identification with certain groups, as well as how they situate themselves in the comparison between groups. On one hand, it can be perceived as an individual's need to conserve their values and to search for complete knowledge (Allport I954, I3-I8). On the other hand, it refers to how individuals recognize their reference group and externalize their knowledge on inter-group relations (Berger 1967, 3-28; Durkheim 1993, 90-99).

Some theoretical propositions mention that ethno-religious identification in most cases is more likely to induce some exclusionary attitudes. Weber (1978, 342, Vertigans 2007,304 ) claims that certain ethno-religious groups exclude other groups by making use of ethno-religious identities to maintain and enhance their position in intergroup relations. Another explanation given by Turner (I999, 6-34) is that a group employs their identities in an exclusionary manner when individuals categorize themselves related to membership in a relevant group, the group identity is salient in relation to comparative judgment, and both the in-group and out-group are interrelated in a field of competition. The dimensions of intergroup comparison are related to differences in intergroup status, and out-group statuses are related to the particular comparative judgment.

This paper will summarize several arguments about how ethno-religious identification leads to contact avoidance at the individual level. First, individuals who possess strong religious identification tend to support exclusionary reactions because extrinsic values of religious convictions may contribute to creating intergroup bias (Allport, I966: 456). In addition, some religious practices and doctrines of particularism are related to prejudicial attitudes towards minority groups (Scheepers et al., 2002a: 242-265). Finally, Sanford (I969:220) argues that the acceptance of religion as an expression of submission to parental authority is a condition favourable to ethnocentrism, which in turn leads to contact avoidance. ${ }^{2}$

2 The need to maintain a positive distinction between in-group and out-group may lead to attitudes that are in favour of the in-group and against out-group. Prej-
The following study describes how ethnoreligious identification is related to both social avoidance, avoidance of future spouse and residential segregation. Tabory's study on the relation between religious and non-religious Jews in Israel shows that religious identification leads to social avoidance and support for residential segregation (I993:I60). He explains that ethno-religious groups live in closed communities to prevent their lifestyles from being impinged upon. Other research by Waterman and Kosmin (1988:79) on the residential patterns of Jews in London explains that the motivation to live in residential segregation is to maintain ethno-religious values and to live separately from the general population. To what extent is ethno-religious identification present among Muslims and Christians in Ambon and Yogyakarta? In which ways is ethno-religious identification among Muslims and Christians observable in their daily lives?

\section{THEORETICAL FRAMEWORK}

Theories about sources of group conflict are contrasted with psychological theories that propose intergroup conflict as projective expressions of problems that are essentially intra-group or intra-individual in origin (Levine and Campbell, I972:29). As mentioned by Tajfel and Turner (I986:7), this theory is different from much of the work in social psychology that emphasizes intra-individual or interpersonal psychological processes that create prejudiced attitudes or discriminatory behaviour. For example, experiments conducted by Billig and Tajfel (1973:27-52) point out that conflict is not necessarily always conflicts of interest or a history of dispute between groups. Tajfel and Turner (I979[1986]) and Tajfel argue (1970: 96-I02) that competition between groups or conflicts of interest are not a necessary condition for discrimination, but merely social categorizations.

Every society consists of social categories, defined as divisions of people that are based on nationality, race, class, religion, and occupation which stand in power and status relations to one another (Abram, I990:I3). Social categories do not exist in isolation, so they naturally lead to the creation of a distinctive social structure.

udiced, intergroup conflict and stereotyping arises from the struggle to maintain positive social identity (Wolfe and Spencer, I996:I77). 
This point of view from social psychology is in line with the sociological theories of structuralism from Weber (1930), Durkheim (I893 [1933]), Parsons (I95I), and Merton (1957). The social identity approach in social psychology attempts to explain the representation of individuals in one's group. Psychological processes create identity and behaviour, including group behaviour. These theories date back to Sumner (I906[I960]:27) who emphasizes the differentiation between in-group or "us," and out-group, or "others." The former refers to peaceful relations, and the latter refers to war relations. Sumner considers ethnocentrism to be group behaviour. His theory is the basis for the further exploration of social identity in the literature of sociology and social psychology.

The rise of social identity theory begins from critiques of realistic conflict theory, by saying that theories of identity should pay attention to the processes underlying the development of group identity, and the subjective aspects of group membership (Tajfel and Turner, I986:8). Social identity theory attempts to explain attitudes and behaviour between social groups through psychological processes that emphasize the development and maintenance of a group's identity, and the impact of group identification on behaviour between groups (Gijsberts et al., 2004:8). Differing from Barth's conception that identification and collectivity are constructed through transaction and negotiation, ${ }^{3}$ Tajfel says that it is merely group membership that is sufficient in itself to generate identification with that group and to channel behaviour toward in-group favouritism and discrimination against an out-group (Jenkins, I996:7).

Based on experimental research, conflict of interest between groups is not sufficient or necessary to produce conflict and discrimination (Turner, I98I). Therefore, the central assumption of this theory is that in-group bias is an omnipresent characteristic of intergroup relations. ${ }^{4}$ Tajfel and associates provide evidence

3 Collective identity is never frozen, and is constantly in flux. Consequently, social boundaries are built through a combination of many varieties of elements and can always be contested. The membership in a collectivity is socially constructed and based on continuous social interactions that share certain features of similarity (Eisenstadt and Giesen, I995:97).

4 Jelen's study (I993: I78-I79) on religious group attitudes explains that ethno-religious group identification is one of the most important predictors of political attitudes among religious and political elites, as well as the public masses. However, Rubin and Hewstone (2004:823830) criticize social identity theory as overemphasizing in-group favouritism and underemphasizing out-group favouritism, and furthermore its inability to explain institutional discrimination. that social categorization is sufficient to create intergroup discrimination and actions favouring the in-group. ${ }^{5}$ In terms of in-group favouritism, Tajfel and Turner (I986:I4) say that maximum difference (MD) is more essential than maximum in-group profit (MIP).

According to this theory, individuals' evaluation of self is a function of both personal and social identity (Herring et al., I999). Personal identity depends on individual accomplishment and is also a product of group membership. In order to maintain a positive self-evaluation, individuals make favourable references to the in-group, which they identify with, and unfavourable ascriptions to out-groups. This theory assumes that individuals categorize their world into them and us. Identification is a motivational need to create positive distinctions, which are fulfilled by social comparisons between groups. Comparisons between the ingroup and out-groups are signified by perceptual overstatements favouring the in-group (Greene, I999: 394). Therefore, social categorization will lead to this kind of perceptual contrast (Turner et al., I987; cf. Greene, I999:394). Social identification, social categorization, and social comparison will produce biased perceptions of the in-group towards out-groups.

As previously mentioned, social identity theory has four important concepts: social categorization, social identification, social comparison, and psychological group distinctiveness. (Tajfel, I978a; Gijsberts et al., 2004: 9). Social categorization, as defined by Tajfel (1978b: 6I) "can be understood as the ordering of a social environment in terms of groupings of persons in a manner which make sense to the individual." It is considered a system of orientation that helps to define the individual's position in society. The difference between in-group and out-group is created by social categorization, a cognitive instrument that systematizes the complexity of information a human organism accepts from their environment. Social categorization takes place when information on social groups is

5 Brewer (I999:442) says that in-group favouritism and identification do not directly correlate with discriminatory perception and behaviour against an out-group. He argues that the need to justify in-group values is related to forms of moral superiority, sensitivity to threat, social comparison processes, the anticipation of interdependence under conditions of distrust and power politics which can bridge in-group identification to create hostility against an out-group. 
organized so that the similarities and differences between categories are emphasized. ${ }^{6}$ Therefore, the difference between categories within the ingroup is perceived as peripheral, and similarities between categories within the in-group become central. Out-groups are defined as a group with members who uniformly share values, conceptions, and feelings; meanwhile, the characters of the in-group are regarded as more diversified.

Tajfel (1978a:63) says social identification is understood as part of an individual's selfconcept, which derives from his knowledge of his membership in social groups, along with the value and emotional significance attached to that membership. Every individual obtains his or her image of self from his or her knowledge of membership in a social group that is attached to a sense of value and emotion in regards to that membership. Social identity can only be defined through the effect of social categorization that segments individuals' social environment into in-groups and out-groups. Social identity can be either positive or negative, depending on the evaluation by the social group that contributes to the formation of the social identity of individuals. This assumes that individuals strive to acquire or maintain a satisfying image or concept of self, or a positive social identity.

Meanwhile, individuals perceive the features of their own in-group as having higher moral values via the social comparison process. This is rooted in Festinger's (1954) hypothesis, which states: (i) "there exists, in the human organism, a drive to evaluate his opinions and his abilities; (ii) to the extent that objective, nonsocial means are not available, people evaluate their opinions and abilities by comparing them respectively with the opinions and abilities of others" (Tajfel, I978:64). Social comparison happens when we make comparisons between others and ourselves. According to Turner (I978:236), to achieve positive social identity, comparisons between the in-group and the out-group must be perceived as differences

6 If the negative out-group orientation is not a strong element of group identity, social categorization may not be accountable for how someone relates to his or her reference group members. Therefore, culture may be one way that individuals find out the meaning and value of the group, and may contribute to collective identity formation (Herring et al., I999:379). that favour the in-group. Festinger suggests that the difference between individuals in an evaluative dimension of performance can be conceptualized as status difference (Turner, I978:237). This social comparison paves the way for creating and maintaining distinctive psychological groups.

If social systems contain hierarchically structured social categories, individuals cognitively simplify and order their perceptions and experiences in order to understand and to act. People categorize others on the basis of their similarities and differences to the self, by which they perceive others as members of the same category as the self (in-group members), or as members of a different category than the self (out-group members) (Abram, I990:I9). Furthermore, individuals identify with their in-group, this social identification represents the extent to which the in-group is incorporated into the sense of self and, at the same time, the self is experienced as an integral part of the in-group (Brewer, 200I:III). Social identification does not produce group behavior because it only creates a positive image of the in-group. Both social categorization and comparison however operate together to generate a specific form of group behavior involving intergroup differentiation and discrimination, in-group favouritism, stereotype perception, conformity to group norms, and affective preference for in-group over out-group (1990: 22). Despite each contributing to the formation of group behavior; both social categorization and comparison have some differences. If social categorization leads to stereotype perceptions of in-group and out-group, and stresses intergroup differences, social comparison explains the selectivity of the accentuation effect, and the magnitude of the exaggeration of intergroup difference and similarities (I990:22). ${ }^{7}$

Social identity theory answers questions about why people like their in-group, and

7 Social self-identification occurs when someone falls into a relatively separate subsystem of self-conception, namely social identity, which comes from membership within social categories (Abram and Hogg, I990: 22). Due to the fact that social self-identification is essentially social self-categorization, it is not difficult to generate a principle that determines the salience of social identity. Essentially, within any given social frame of reference, those social categories will become salient. 
dislike out-groups (Coenders, 200I:24). In summary, the basic standpoint of this theory is that individuals struggle for a positive self-concept. Social identity is part of an individual's selfconcept, which comes from the process of social categorization and comparison. Furthermore, individuals struggle for a positive social identity and determine the relative status and value of their in-group through social comparison with out-groups. Finally, individuals struggle for positive in-group distinctiveness, and have positive attitudes toward their in-group and negative attitudes towards out-groups.

\section{METHODS}

Surveys were conducted among students at the undergraduate level with a minimum of second year standing from six universities in Ambon and Yogyakarta. We chose students from the second year onwards because they have had sufficient time to engage in social interactions with classmates, board mates and neighbours from different ethno-religious groups. Post-graduate students were not selected as they were not involved directly in daily life of university based organizations. Students in Indonesia are part of the middle class, generally have sufficient knowledge and experience to utter rational statements and to determine their attitude consciously and rationally. University student unions organize demonstrations, rallies, and training for activists against unpopular government policies. The fall of authoritarian regimes in 1966 and 1998 were related to rising student movements. After 1998 , the process of electing leaders of student unions often became a site of political contestation among religious or ethnic organizations. In conflict areas, student unions are politicized groups but are not necessarily affiliated with groups that are allegedly responsible for violence or with politicized ethno-religious organizations. Student groups have also been involved in conducting peace activities to promote reconciliation between ethno-religious groups that have been involved in conflicts (Sterkens et al., 2009: 3).

The surveys were carried out at the beginning of the academic year in September of 2oII, so one could not reasonably expect that first year students had already had enough contact opportunities at that stage. The universities chosen were purposely selected by considering the representation of religions at each institution. The universities selected were University of Gadjah Mada, (Universitas Gadjah Mada, UGM), State Islamic University of Sunan Kalijaga (Universitas Islam Negeri, UIN Sunan Kalijaga), and Christian University of Duta Wacana (Universitas Kristen Duta Wacana, $U K D W$ ) in Yogyakarta; and University of Pattimura (Universitas Pattimura, Unpatti), State Islamic Institute of Ambon (Institut Agama Islam Negeri, IAIN Ambon), and Indonesian Christian University in Maluku (Universitas Kristen Indonesia Maluku, UKIM) in Ambon. The main reasons that we chose these six universities are that two of the universities (UKDW and UKIM) house a majority of Christian students, two of the universities house a majority of Muslim students (UIN Yogyakarta and UIN Ambon), and the others possess a heterogeneous population of students from various religious groups (UGM and UNPATTI). UGM and UNPATI were selected due to their roles as centres of education in their areas that have secular orientations, but are also arenas of political contestation for religiously-based student organizations.

The definite survey was carried out in three universities in Ambon (Unpatti, IAIN Ambon, UKIM), and three universities in Yogyakarta (UGM, UIN Sunan Kalijaga, and UKDW) from September to December of 20II. The overall goal of the sampling procedure was to collect a random sample from students in their second and third years of the BA program, in order to present a generalization of the student population. In each university, 250 students were selected by systematic random sampling. The following steps were carried out when conducting the survey in Ambon. First, we collected a list of students from every faculty to serve as the sampling frame. ${ }^{8}$ We then conducted systematic random sampling based on the proportion of

8 During religious violence in Ambon on the $15^{\text {th }}$ of July 20II, the registration office of Unpatti was burnt down; and in communal violence on September $\mathrm{II}^{\text {th }}$, 20II, the administration building of UKIM Ambon was destroyed. Consequently, the newest student enrolment lists for Unpatti and UKIM were destroyed. We used enrolment lists from the second semester of 2010 as a sample frame for these institutions. 
the student population in every faculty within the university. The interval number was found by dividing the population of each faculty with the number of respondents. An invitation was sent to respondents with the assistance of university staff or the student union in each faculty. After that, respondents were gathered in one place to fill out the questionnaires under the supervision of the researcher. ${ }^{9}$

The survey procedure in Yogyakarta was similar to the procedure in Ambon. ${ }^{10}$ Firstly, a list of the students attending the three universities was obtained in the form of a digital file. The data in Yogyakarta was gathered at the university level, rather than at the faculty level as in Ambon. Secondly, we implemented random sampling directly by using a set of random numbers obtained by a computer program. Thirdly, we sent invitation letters that were distributed by the department heads to the respondents, asking them to gather in particular places within their universities. Finally, the surveys were conducted in the classrooms referred to in the invitation. These procedures were applicable at both UGM and UIN Sunan Kalijaga. However, at UKDW, several research assistants visited respondents in their dormitories to distribute the questionnaires.

We subsequently employed analysis of variance (ANOVA) to identify whether there were differences between means, (Field, 2009:349). If sample means are $\bar{Y}_{1}, \bar{Y}_{2}, \bar{Y}_{3, \ldots} \bar{Y}_{k}$ then we used ANOVA to ascertain whether the sample means were significantly different. If the F-ratio was significant $(\mathrm{p}<.05)$, then the hypothesis was not rejected, which means that the differences between means are significant. This analysis also generates linearity and

9 This manner of inviting respondents was applicable in Unpatti (in the Agriculture, Technology, Education, and Economy faculties). However, at IAIN Ambon and some faculties in Unpatti (Law, Fisheries, Science, and Social Science) we used a different approach. Student executive boards identified respondents from a random list and distributed questionnaires. The next day, they collected the questionnaire from the respondents. In UKIM, university staff members distributed questionnaires to respondents, and respondents filled these out at home. After one week, these respondents submitted their questionnaire to the university staff.

Io Tri Subagya managed the survey distribution during his fieldwork in Yogyakarta from September to December 2 oII. correlation coefficients. Pearson-r is for linear relationships, while eta is for non-linear relationships.

Ethno-religious identification includes three primary dimensions reflected at the individual level: cognitive (knowledge), evaluation (value), and affective (emotion) (Tajfel, I98I; Gijsberts et al., 2004). The term refers both to religious identification and ethnic identification. Questions regarding these variables were taken from the models provided in Tuti's (2007) and Handi's (2008) questionnaires, which focus on ethnic and religious identification in Indonesian society. In addition, we added some questions from ESS (2008) since these questions touched on conscious self-identification. We conducted a factor analysis separately for Muslims and Christians because the questions on religious ceremonies were different.

According to Phinney and Rotheram's concept of ethnic identity (1987), we define religious identification as one's sense of belonging to a religious group and the part of an individual's thinking, perceptions, feelings, and behaviours related to their religious group membership. Religious identification is a process in which individuals obtain their image of self from their knowledge of membership in a religious group, including the value and emotional significance of the group (Tajfel, I98I; Gijsberts et al., 2004). Based on this definition, religious identification consists of religious self-definition, attendance at religious practices and ceremonies, friendship by religion, membership and participation in religious organizations, and political orientation.

\section{FINDINGS}

\section{Religious self-definition}

Based on interpretations drawn from previous research, religious self-definition is an individual subjective feeling, acknowledgement, and recognition through verbal statements about an individual's membership in a certain religious group that represents their religious identity. Therefore, the question of religious self-definition is "What religion do they consider themselves to belong to?" In this question, the 
term to 'consider' means that respondents will think and consciously affiliate themselves with a certain religion. Religious self-definition will be measured by asking respondents whether they consider themselves to be Muslim, Christian, Catholic, Hindu, or Buddhist. This question of self-definition was formulated as, "To what religion do you consider yourself to belong to?"

This data shows that Javanese, Butonese, Sundanese, Madurese, and Minangkabaunese respondents are mostly Muslims. In contrast, the Christian respondents are mostly Ambonese, Chinese, Bataknese, and Torajanese.

\section{Self-definition in practice}

In the following section, we describe how ethnic identity is expressed, given that respondents' ethnic identities are more varied than their religious identities. Based on the interviews, we are able to illustrate how respondents identify with their religious or ethnic groups. All of our informants mentioned their religious identities during the interview, which is common in Indonesia since everyone is required to adhere to one of the six official religions. However, several respondents also mentioned their ethnicity;

Table I. Cross tabulation between ethnicity and religious groups $(\mathrm{n}=\mathrm{I} 444)$

\begin{tabular}{llllll}
\hline \multirow{2}{*}{ Ethnic groups } & \multicolumn{4}{l}{ Religions of respondents } & \multirow{3}{l}{ Thristian } \\
\cline { 2 - 5 } & \multicolumn{2}{l}{ Muslim } & \multicolumn{4}{l}{ Total } \\
\cline { 2 - 5 } Javanese & 348 & 41.83 & 104 & 16.99 & 452 \\
\hline Sundanese & 36 & 4.33 & 2 & .33 & 38 \\
\hline Madurese & 36 & 4.33 & & & 36 \\
\hline Minangkabau & 17 & 2.04 & & & 17 \\
\hline Ambonese & 241 & 28.97 & 346 & 56.54 & 587 \\
\hline Buginese & 10 & 1.20 & & & 10 \\
\hline Makassarese & 2 & .24 & 1 & .16 & 3 \\
\hline Butonese & 95 & 11.42 & & & 95 \\
\hline Torajanese & & & 20 & 3.27 & 20 \\
\hline Minahasa & & & 5 & .82 & 5 \\
\hline Chinese & 1 & 1.20 & 43 & 7.03 & 44 \\
\hline Bataknese & 2 & .24 & 35 & 5.72 & 37 \\
\hline Others & 44 & 5.29 & 56 & 9.15 & 100 \\
\hline Total & 832 & 100 & 612 & 100 & 1444 \\
\hline
\end{tabular}

some respondents referred to their parents' identities, while other respondents talked about places where they grew up.

Many respondents categorize their ethnicity directly. Josep Ufi, a Catholic informant in Ambon, said, "I belong to the Kei ethnic group." Fauzi, a Muslim informant in Yogyakarta, said, "I am proud to be a Javanese." Most answers indicate that respondents inherited their ethnic identities from their parents, even in cases where respondents migrated from their ethnic regions and do not speak their ethnic language properly. Ahmad, a Muslim informant, was born in Sumatra, but his parents migrated from Java to Sumatra more than twenty years ago. With respect to his identity, he explained that "Well, I see myself as Javanese. I was born and brought up in an environment in which Javanese people are the majority. Although I live in an area with Malay people, my community is still Javanese."

Nevertheless, sometimes ethnicity is fluid. Several respondents tell that they use their ethnic identities functionally depending on the occasion. A Muslim informant, Fitri, gave an example. She was born in Masohi, in Central Moluccas, from a Butonese father and an Ambonese mother. She speaks both Butonese and Ambonese. When asked about her identity, she said:

"I declare myself Butonese only when I meet people from Buton. However, I say I am Ambonese in front of common people. On campus, I consider myself Butonese, but I also often say I come from Ambon or Seram. If I meet people at the market, I say I am both Ambonese and Butonese. But it is more comfortable to be Butonese, because Ambonese are associated with horrible, stubborn, and rough behaviour."

Many informants in Ambon did not directly state their ethnicity, but only mentioned their hometowns or family names. Unlike other provinces in Indonesia, the Moluccas has consisted of villages divided according to religious and ethno-linguistically related groups since the $\mathrm{I} 7^{\text {th }}$ century. Moreover, each family name belongs to a specific Christian or Muslim village. For example, Souwakil is a family name in Ambalau, Southern Buru Island, and people with this family name are mostly Muslim. Soselisa is a family name in Saparua and 
people with this surname are mostly Christian. Ufi is a family name in the Kei islands, and those who carry the name are mostly Catholic. Consequently, among the Ambonese or Moluccans, religious and ethnic identities are easily recognized through geographic associations and family names. Therefore, when our informants stated only their family names or hometowns in interviews, it was assumed that we would recognize their ethnicity and religion. For example, an informant introduced herself by saying, "My name is Iftiyah Salwa Tuanany from Kailolo." This indicated that she is from the Hatuhaha ethnic group and that she is a Muslim. Another informant said, "My name is Eric Weruatwarin from Wetlaar, Kei Islands, indicating that he is Catholic from the Kei Islands.

\section{Religious Identification in Practices}

Based on Hadiwitanto (2008), Tuti (2007), and ESS (2008) research, religious identification has several dimensions, including religious ceremonies, religious practices, religious friendships, and membership and participation in religious organizations.

\section{Religious ceremonies and practices}

We asked Muslims and Christians about how often they attend religious ceremonies and participate in religious practices of their own religious traditions. The questions about religious ceremonies are posed through the Likert scale. For example, we ask, 'could you indicate whether you participate or not in ... (religious ceremony)?' The questions on religious practices ask about quantity, such as 'How often do you go to religious services in mosques, churches, or other places of worship?' We conducted a factor analysis separately for Muslims and Christians because the questions on religious ceremonies are different. We excluded the observation of Isra Miraj and Maulud since Muslims do not widely celebrate these collective rites.

The first step (Muslim respondents) produces three factors: collective rites (fasting,
Idul Fitri and Idul Adha), rites of passage (marriage, circumcision, and funeral), and religious practices (praying, religious services, and reciting the Holy Scriptures). The second step (Christian respondents) results in two factors: religious ceremonies and religious practices. The question on fasting is excluded from the next step because of low communality $(<.20)$. In the third step (Muslim respondents), we split the factor analysis into two factors in order to adapt to the result of second step (Christian respondents). However, the result is not statistically viable because it only consists of collective rites and rite of passage. In the fourth step (Christian respondents), we divided the factor analysis into three factors in order to adapt to the result of the third step (Muslim respondents). The three factors are: collective rites (Christmas and Easter), rites of passage (marriage and funeral), and religious practices (praying, religious services, and reciting the Holy Scriptures). The question on baptism is excluded because it loads highly in two factors (>.30). The correlation between the three factors are significant $(\mathrm{p}<.05)$ and moderate $(\mathrm{r}<.60)$.

The reliability of collective rites is very high both for Muslim (.96) and Christian respondents (.98). Rite of passage is also high for both groups (.78 and .79), while religious practices are moderate for Christian respondents (.6o) and are low for Muslim respondents (.48). Rite of passage consists of four answer categories: $I d o$ not participate in it and neither does my family (I), I do not participate in it but my family does (2), I do participate but for non-religious reason (3), and I do participate for religious reason (4). Collective rites is composed of three categories: I do not participate in it and neither does my family (I), I do not participate in it but my family does (2), and I do participate but for non-religious reasons and religious reasons (3). Religious practices has six categories: never and only on feast days (I), at least once a month (2), once a week (3), more than once a week (4), once a day (5), and several times a day (6). 
Table 2. Factor analysis for religious identification

\begin{tabular}{|c|c|c|c|c|c|c|c|c|}
\hline \multirow{3}{*}{$\begin{array}{l}\text { Scale label } \\
\text { for full population }\end{array}$} & \multicolumn{4}{|c|}{ Muslims } & \multicolumn{4}{|c|}{ Christians } \\
\hline & \multirow[t]{2}{*}{ Com. } & \multicolumn{3}{|c|}{$\begin{array}{l}\text { Factor loadings } \\
\text { Pattern matrix }\end{array}$} & \multirow[t]{2}{*}{ Com. } & \multicolumn{3}{|c|}{$\begin{array}{l}\text { Factor loadings } \\
\text { Pattern matrix }\end{array}$} \\
\hline & & $\begin{array}{l}\text { Coll. } \\
\text { rites }\end{array}$ & $\begin{array}{l}\text { Rites pas- } \\
\text { sage }\end{array}$ & Practices & & $\begin{array}{l}\text { Coll. } \\
\text { rites }\end{array}$ & $\begin{array}{l}\text { Rites } \\
\text { passage }\end{array}$ & Practices \\
\hline $\begin{array}{l}\text { 28. Participation in religious } \\
\text { ceremonies/rituals: Idul Fitri/ } \\
\text { Christmas }\end{array}$ & .97 & .98 & & & .97 & .98 & & \\
\hline $\begin{array}{l}\text { 29. Participation in religious } \\
\text { ceremonies/rituals: Idul } \\
\text { Adha/Easther }\end{array}$ & .93 & .94 & & & .96 & .96 & & \\
\hline $\begin{array}{l}\text { 27. Participation in religious } \\
\text { ceremonies/rituals: Fasting }\end{array}$ & .80 & .87 & & & & & & \\
\hline $\begin{array}{l}\text { 25. Participation in religious } \\
\text { ceremonies/rituals: Marriage }\end{array}$ & .72 & & .86 & & .65 & & -.83 & \\
\hline $\begin{array}{l}\text { 24. Participation in religious } \\
\text { ceremonies/rituals: Circumci- } \\
\text { sion }\end{array}$ & .47 & & .67 & & & & & \\
\hline $\begin{array}{l}\text { 26. Participation in religious } \\
\text { ceremonies/rituals: Funeral }\end{array}$ & .49 & & .61 & & .66 & & -.75 & \\
\hline 38. How often do you pray? & .17 & & & .72 & .26 & & & .50 \\
\hline $\begin{array}{l}\text { 39. How often do you go to } \\
\text { religious services in mosques, } \\
\text { churches, temple or other } \\
\text { places of worship? }\end{array}$ & .20 & & & .41 & .27 & & & .51 \\
\hline $\begin{array}{l}\text { 57. How often do you read } \\
\text { or recite the Holy Scripture } \\
\text { (Koran, Bible, Vedas, or } \\
\text { Tripitaka)? }\end{array}$ & .51 & & & .41 & .62 & & & .80 \\
\hline Initial eigenvalues & & 3.63 & 1.57 & 1.23 & & 2.90 & .74 & 1.74 \\
\hline$\%$ of variance (extracted) & & 38.02 & 11.89 & 8.43 & & 39.16 & 6.47 & 17.08 \\
\hline Reliability $(\alpha)$ & & .96 & .78 & .48 & & .98 & .79 & .60 \\
\hline
\end{tabular}

$N$ (number of respondents) $=827$ (Muslim) and 591 (Christian)

The questions on religious friendship ask respondents how many of their friends have the same faith as them. This measurement is divided into two dimensions: religious in-group friends and religious out-group friends. This is in line with our conceptual framework that among individuals, the more friends they have from the religious in-group, the more likely it is that they avoid contact with people from different religions. In contrast, the more friends they have from religious out-groups, the less it is that they avoid contact with people from different religions. We compute both dimensions based on the maximum values because the questions emphasize the quantity of friends. The answer categories for both dimensions are recoded by combining I (none) and 2 (some) into I to get a normal distribution curve. The results are none and some (I), relatively many and many (2), almost all (3), and all (4).

Another dimension related to religious identity is membership and participation in religious organizations. The question about membership asks whether respondents are members, followers, or members. We recoded the answer category to non members (o) and members or followers (I). The question about religious participation asks about the frequency of respondents to participate in any religious organization, from never to more than once a week. 


\section{Ethnic identification}

The measurement of ethnic identification consists of several dimensions, such as ethnic self-definition, ethnic ceremonies, ethnic languages, friendship by ethnicity, and membership and participation in ethnic organizations.

The questions on ethnic ceremonies inquire about births, weddings, moving home, illnesses, and funerals. We ask respondents, 'Could you indicate whether you know these ceremonies and whether you and/or your family participate or not in these ceremonies.' The answer category consists of no knowledge (I), I do not participate in it and neither does my family (2), I do not participate in it but my family does (3), and I do participate (4). The reliability of four questions is relatively high for both of the groups (.79), with Muslim respondents at (.76), and Christian respondents at (.8I).

The questions about ethnic languages refer to languages ordinarily used at home, with families, at universities, with close friends, in communities, and with government officials. In Indonesia, the everyday language used could be in a language or dialect different from the national language. The highest reliability-as presented by the Cronbach alpha-is for Christian respondents (.8I), while the value of Cronbach alpha for Muslim respondents and both groups are .70 and .75 , respectively. We computed the number of occasions when respondents speak their ethnic languages. Lastly, we recoded the use of ethnic languages to obtain a normal distribution, therefore the ethnic languages have four intervals: never (o), one or two occasions (I), three or four occasions (2), and five or six occasions (3).

Friendship by ethnicity is referred to as social embeddedness. These questions ask about the numbers of friends from the same ethnic group that a respondent has, ranging from none to all. The reliability of the questions is relatively high, as revealed by the Cronbach alpha for both groups (.88), Christian respondents (.8I), and Muslim respondents (.77). We computed the relative number of friends who belong to a respondent's ethnic group ('homogeneous friends'). We expected that intergroup contact avoidance is stronger for those who have many friends from their own ethnic group. Here, we recoded social embeddedness into fewer categories to obtain a normal distribution by combining the available answers between none and some. Social embeddedness contains four answer categories: none and some (I), relatively many (2), almost all (3), and all (4).

These questions focus on membership and participation in ethnic organizations. We ask whether respondents are not members, followers, or members of ethnic organizations. We recoded the answer category to not members (o) and followers or members (I). Meanwhile, the question on participation asks how often respondents participate in any ethnic organization, from never to more than once a week.

Survey findings showed that most respondents celebrate Idul Fitri, Idul Adha, and Christmas. From the interviews, we find that almost all respondents celebrate these feast-days together with their families in their hometowns. Muslim communities in Ambon and Yogyakarta collectively celebrate Idul Fitri and Idul Adha. Christian communities hold Christmas parties in Ambon and Yogyakarta. In Maluku, the Idul Adha celebration contains traditional rituals where animals that will be slaughtered in the celebration are paraded around the neighborhood, and can include the reactivation of cultural bonds between villages. Iftiyah, a Muslim informant from Kailolo of Haruku Island said:

"At the Idul Adha celebration on Haruku Island, we have hadrats [parade]. There [in Kailolo of Haruku Island], we also have a ceremony to reactivate pela [the cultural bond] after the Idul Adha. We have it every year. In Ambon, we celebrate Idul Fitri in lapangan merdeka [city square] and celebrate the Idul Adha at a mosque in a housing complex."

In rural Maluku, Islamic ceremonies apparently are still intertwined with adat rituals, differing from local Christian ceremonies. This is due to the historical practice of placing Muslim preachers under the adat structure (Bartels, 200I:I39-I40).

Respondents provided varied responses in regard to the frequency of their mosque and church visits. Some respondents report that they go to the mosque every day, and at the 
other end of the spectrum, some said they only go during special events. A Muslim informant, Fitri, said:

"I go to the mosque only on Islamic celebration days like Isra Miraj [ascendence of the prophet] and Maulid Nabi [the birthday of the prophet] and I am only a participant. Also I went to the mosque for shalat tarawih [collective praying in the night during fasting month]."

Another Muslim informant, Syamsuddin, goes to the mosque almost every day. He says: "I perform shalat [religious services] in the campus mosque, but subuh [dawn praying] in Musholla Al-Kalam." This mosque belongs to a community that is politically affiliated to PKS, the Prosperous and Justice Party, one of the Islamic parties in Indonesia. Most Christians go to church every Sunday. A Christian informant, Beatrice, mentioned: "I only go to the church on Sunday to participate in mass and to teach children in a Sunday school." We did not find Christian informants who would go to church on Christian holy days only.

Praying is an important activity in the lives of both Muslims and Christians. Survey findings demonstrated that most respondents pray to God several times a day. In the interviews, some respondents confirmed this. For example, Syamsuddin mentioned "doa [praying] was conducted several times a day, after every shalat [religious services]. That kind of praying is general, which is to pray for safety of parents, pray for safety in world and hereafter. There are also special moments for praying, like when dealing with exams." A Christian informant, Beatrice, explained: "I pray routinely before and after eating, sleeping, and going to campus. I also pray in special moments with God every day, between 12.00 and 02.30 or between 5.30 and o6.0o."

Another aspect of religious identification is reading the Holy Scriptures. Survey findings revealed that most Muslim and Christian respondents recite their Holy Scriptures at least once a day. In the interviews, many Muslim respondents mentioned that they recite the Quran after sunset, while most Christian respondents read the Bible during Sunday mass and in the Morning Prayer. A Muslim informant from Yogyakarta, Yusira, gave an example. When asked about when she recites the Quran, she replied, "after magrib [sunset praying], when there is enough time after subuh [sunrise praying]." Hery, a Christian informant from Yogyakarta says that he reads the Bible during the Morning Prayer.

Many respondents say that they have more friends belonging to their own religious groups than from other religions. However, several also mention that they have some friends from other religions, despite the residential religious segregation in the city of Ambon. For example, Iftiyah, a Muslim informant, was asked whether she has Christian friends. She said, "I have some. They are in Passo and in Karpan, and some of them live behind Soya. We begin to know each other when participating in an English debate in Yogyakarta. At that time, I was in the third year of SMK [specialist senior high school]." A Catholic informant, Eric, has many Muslim friends. "I socialized with Muslims in SD [primary school], SMP [junior high school] and SMA [senior high school]. I had even lived with a Muslim family in Tual, the family of my classmate. In [student] associations, university, and GMNI [the Indonesian National Students Movement], we also have Muslim friends." A Protestant informant, Hery, says, "I have more Christian friends, but I have Muslim friends, too."

Another aspect of religious identification is participation in either religious organizations on campus or mass-based religious organizations outside campus. As mentioned earlier, several campus-based religious organizations were founded before the political reformation in 1998 , such as the Campus Islamic Preaching Institute (Lembaga Dakwah Kampus, LDK); the Association of Christian University Students (Persekutuan Mahasiswa Kristen, PMK); and the Association of Catholic University Students (Keluarga Mahasiswa Katolik, KMK). In Ambon, several mass-based religious organizations were established during the colonial period, such as the Youth Forces of Moluccan Protestant Churches (Angkatan Muda GPM, AM-GPM) and the Association of Muhammadiyah Teenagers (Ikatan Remaja Muhammadiyah, IRM). 
Although the survey findings showed that only a small percentage of respondents join religious organizations, it is worthwhile to give some examples. A Muslim informant in Ambon, Fitri, stated, "I just participated in LDK. Our activities are studying religion [Islam] with various weekly topics. For examples are about daily life, fiqih, Islamic laws, and how to dress in Islam. In my village [Masohi], I participated in IRM at Al-Muhajirin mosque." A Christian informant, Richo, explains, "I was a former teenage-chairman of AM-GPM at Bethel church, Mardika. I was then involved in the leadership of youth generation. Next, I was elected as a head of department at or the Indonesian Christian Students Movement [Gerakan Mahasiswa Kristen Indonesia, GMKI] of Economic-Unpatti."

Like religious identification, ethnic identification includes participation in ethnic ceremonies and organizations, ethnic language use, and friendship by ethnicity. As mentioned earlier, the survey findings indicated that most respondents participated in ethnic ceremonies, mainly weddings and funerals. The interviews also found that many respondents participated in ethnic ceremonies. A Muslim Butonese informant, Fitri, says, "I have also been a receptionist for a wedding committee. I was someone who delivered the property of the brides; there were scissors, blades [for women]; a long cloth from the man bride. Then, as customs require, was a pot for betel leaf." Although ethnic ceremonies are not popular in Christian villages in Ambon, they are still conducted in Catholic villages in the Southeast Moluccas. A Catholic informant, Eric, explains:

"For adat ritual activities, we were involved even in our childhood. For example, requests for marriage, marriage, and funeral rituals. There are rituals where children are involved as anak adat [sons of native]. Without considering whether they are the first, second or third born child, from a Catholic, Muslim or Protestant family, if they are anak adat, they are given the chance to speak out at funerals. They speak in the release of the dead."

Our survey findings revealed that Muslim respondents speak their ethnic language on more occasions than Christian respondents do.
In the interviews, more than one respondent said that they speak in ethnic languages. A Muslim informant, Iftiyah, says, "Our language is the Ambonese language because we have been living here a very long time. In Tulehu, I actually spoke the Kailolo language, but after moving here I completely forgot it because we speak the Ambonese language now." Karim, another Muslim informant, adds:

"Yes I speak in Sepa language. I learned it from my family. It was a traditional language. I began to learn it during childhood. In Sepa, we learned two languages, Ambonese-Malay and the mother tongue of our region. This language is used for talking about secret matters."

A Catholic informant, Eric, says he can speak his ethnic language since he comes from the Southeast Moluccas. "I know those [Kei] customs very well," he says. "I speak the language too. I am familiar with all the customs of the Kei ethnic group." Although Christian respondents from Java mostly speak Javanese, Christian respondents from Ambon generally do not speak their ethnic languages since the Malay language replaced their ethnic languages when Dutch missionaries introduced Protestantism systematically in the igth century (Chauvel, I990:4-I4).

Friendship with people of the same ethnicity, a type of social embeddedness, is an important aspect of ethnic identification. It is common for respondents to have many ethnic in-group friends. The interviews also confirm that most respondents have friends from the same ethnic group. Fitri, a Muslim informant, has a Butonese father and an Ambonese mother. She was born and grew up in the Central Moluccas. Unlike other Butonese, she does not use her father's family name, but a common name, similar to the Javanese naming system. In Ambon, she studies at the State Islamic Institute and lives in a boarding house occupied by Butonese students. "In my rented house, almost all my friends are Butonese, they speak the Buton language. I am accepted because I know a little bit of it. But sometimes they mock me, saying that I am a fake Butonese," she says. However, none of our Christian informants mentioned similar issues. 
Another element of ethnic identification is participation in either mass- or campus-based ethnic organizations. Here, we give examples of two campus based-ethnic organizations in Ambon, the Evav Students' Communication Forum (Forum Komunikasi Mahasiswa Evav, Fokusmapa) and the Sepa Students' Association (Ikatan Pelajar Mahasiswa Sepa, IPMAS). A Catholic informant, Eric, says:

"In Ambon, we have Fokusmapa. The main goal of this organization is to unify all student communities from the Southeast Moluccas and Tual City. All people that have blood relationships [with people in the Southeast-Moluccas] are united. They are advised to become a member of this organization. All students from the Kei Islands of Southeast Moluccas, without considering their religions, are welcomed to join in the organization."

This ethnic student organization had around 8000 members studying in higher educational institutes in Ambon. Their activities, according to Eric, include "some seminars on local wisdom in the Southeast Moluccas and collective religious celebrations, such as Christmas, Idul Fitri, and Easter, during which Kei students gather."

\section{About IPMAS, Karim says:}

"We already have I2 branches throughout Indonesia. It is a national organization, with all its members from Sepa. University students or those from any educational institution are included. This organization is open for students belong to negeri [adat village] and petuanan [administrative village]. Students from outside Sepa, who have a Sepa bloodline, have the right to join us."

This organization has around noo members in Ambon and focuses on studying the history of Sepa and Islam.

The interview findings reveal that the growing religious identification is in line with the decrease of ethnic identification. Daud, a Muslim and head of LDK-Unpatti, says:

"In the Moluccas, culture is generally solid and strong. Among the many cultures is the culture of my village in Southern Buru, adat [customary law] is unchangeable, and rather defies Islamic values [believe in God almighty]. Here is an example. Most people still believe in magic. We have laws in the Quran and Hadith but they believe in other parties beside Allah."
According to Daud, people in his village still believe in supernatural powers. For example, during a long period drought, they visited sacred places to pray for help. He and the other people from his village who study in Unpatti have tried to change this tradition to better reflect Islamic values. "Since my SMP [junior high school] years, I was still tied to our culture," he says. "However, after studying in Ambon [Sciences-Unpatti] being introduced to tarbiyah [Islamic preaching] and understanding it [pure Islamic belief], my village-mates and I attempted to change the tradition." When asked which bond is stronger, he says, "I have to say that my bond is to my religion."

\section{SOCIAL DISTANCE AND ETHNORE- LIGIOUS IDENTIFICATION}

The first dimension of social distance is contact avoidance. Our measurement of this dimension consists of nine questions presented to both Muslim and Christian respondents. A Mokken scale analysis (MSA), commonly employed in the analysis of ordinal scale and survey data, is used measure levels of contact avoidance through the following questions: "To what extent would you accept or avoid a Christian as your city/town mayor, civil servant, police officer, neighbor, classmate, board mate, houseboy, close friend, future spouse?"

The second dimension is the avoidance of future spouse from a different religion. This topic is was not included in the questions on contact avoidance based on the Mokken scale analysis. However, we included this question in the dimension of contact avoidance because it is seemed important in the Indonesian context. Individuals in Indonesia could do not always individually choose their spouses. Parents, families, religious norms, and cultural traditions often determine who an individual's spouse will be, rather than the decision about who to marry being a personal choice. Marriages are deemed appropriate if they are arranged and conducted according to the religious regulations (UGM, 20Io). Indeed, many interpretations of religious law in Indonesia forbid inter-religious marriage. Therefore, the question of how religion is involved in choosing a future spouse differs 
from the other questions on contact avoidance, which assumed that individuals consciously and subjectively avoid or accept people from different religious groups. In this study, 'avoidance of future spouse' is a separate dimension of intergroup contact avoidance. Here too, we recoded the five answer categories into two categories: accept (o) and avoid (I). The difference in mean score demonstrates that Muslim respondents (.75) avoid future spouses who believe in another religious tradition more often than Christian respondents (.49) do.

The third dimension is the support for residential segregation, as presented by qI82 (I prefer to live in a neighborhood inhabited by persons of the same religion) to $\mathrm{qI} 85$ (There should be separate neighborhood where the Muslims and Christians could live separately). We do not test the scale by both Mokken scale and factor analysis because the questions only have one dimension, the support for residential segregation. Similar to other dimensions of intergroup contact avoidance, we recoded the answer category into avoid (o) and accept (I). However, before recoding, the scores of question I.83 (I prefer to live in a neighborhood inhabited by persons of different religion) were inverted because they contained a negative formulation. For both groups (Muslim and Christian respondents) and Muslim respondents, the scale shows moderate reliability ( $\alpha=.67$ and .68 respectively). For Christian respondents, however, the scale contained a low reliability $(\alpha=.56)$. Since there are only few questions, respected values are sufficient to indicate that these questions are reliable. The difference in overall mean scores indicates that Muslim respondents prefer to live in residential segregation (.40) more than Christian respondents do (.22), as tested by ANOVA.

In the following section, we present ANOVA between intergroup contact avoidance and ethno-religious identification. Only the significant correlations will be described.

\section{Muslim respondents}

The following section describes the social location of intergroup contact avoidance among Muslim respondents. Participation in rites of passage has a significant effect on contact avoidance and the avoidance of future spouses from a different religion $(\mathrm{p}<$. oI). Among Muslim respondents, we discover that the more they participate in rites of passage, the more they tend to avoid contact with Christians (eta correlation or eta=.13), and the more they tend to avoid Christians as future spouses (eta=.I6). There is a significant relation between attendance in collective rites and the avoidance of future spouses from a different religion $(\mathrm{p}<.05)$. The more frequently Muslims participate in collective rites, the more they tend to avoid Christians as their future spouses (eta= (.o9). The amount of religious in-group friends an individual has significantly affects contact avoidance and the support for residential segregation ( $\mathrm{p}$ <.oI). Among Muslim respondents, we discover that the more Muslimfriends they have, the more they tend to avoid contact with Christians ( $\mathrm{r}$ correlation or $\mathrm{r}=.20$ eta $=.25$ ) and the more they tend to support residential segregation $(\mathrm{r}=.33 \mathrm{eta}=.40)$.

Having religious out-group friends is significantly related to contact avoidance, the avoidance of future spouses from a different religion, and the support for residential segregation $(\mathrm{p}<. \mathrm{oI})$. For Muslim respondents, the more friends from different religions they have, the less they tend to avoid contact with Christians $(r=-.29)$, the less they avoid Christians as their future spouses ( $r=-. \mathrm{I} 7)$, and the less they support residential segregation $(\mathrm{r}=.-.38)$. Membership in a religious organization has an effect on contact avoidance and the support for residential segregation $(\mathrm{p}<$.oI). Muslim respondents who become members or followers of any religious organization tend to avoid contact with Christians (eta=.Io) and membership makes them more likely to support residential segregation (eta=.II). Participation in religious organizations only significantly related to the avoidance of future spouses from a different religion. For Muslim respondents, the more participation in any kind of religious organization, the more they avoid Christians as their future spouses (eta=.I7). 
Table 3. Intergroup contact avoidance and ethno-religious identification

\begin{tabular}{|c|c|c|c|c|c|c|c|c|c|c|c|c|}
\hline & \multicolumn{4}{|c|}{ Contact avoidance } & \multicolumn{4}{|c|}{ Avoidance of future spouse } & \multicolumn{4}{|c|}{$\begin{array}{l}\text { Support for residential segrega- } \\
\text { tion }\end{array}$} \\
\hline & \multicolumn{2}{|c|}{ Muslim } & \multicolumn{2}{|c|}{ Christian } & \multicolumn{2}{|c|}{ Muslim } & \multicolumn{2}{|c|}{ Christian } & \multicolumn{2}{|c|}{ Muslim } & \multicolumn{2}{|c|}{ Christian } \\
\hline & M & $\begin{array}{l}\text { correla- } \\
\text { tion }\end{array}$ & M & $\begin{array}{l}\text { corre- } \\
\text { lation }\end{array}$ & M & $\begin{array}{l}\text { corre- } \\
\text { lation }\end{array}$ & M & $\begin{array}{l}\text { corre- } \\
\text { lation }\end{array}$ & M & $\begin{array}{l}\text { correla- } \\
\text { tion }\end{array}$ & M & $\begin{array}{l}\text { correla- } \\
\text { tion }\end{array}$ \\
\hline Rites of passage & .16 & $.13^{* *}$ & .04 & $.11^{* *}$ & .75 & $.16^{*}$ & & & & & & \\
\hline Collective rites & & & & & .75 & $.09 *$ & & & & & & \\
\hline Religious practices & & & .04 & $.08^{*}$ & & & .49 & $.14^{* *}$ & & & & \\
\hline $\begin{array}{l}\text { Religious in-group } \\
\text { friends }\end{array}$ & .16 & $.25^{* *}$ & .03 & $.14^{* *}$ & & & & & .40 &. $.40 * *$ & .22 & $.25^{* *}$ \\
\hline $\begin{array}{l}\text { Religious out-group } \\
\text { friends }\end{array}$ & .15 & $-.29 * *$ & & & .75 & $-.17^{*}$ & & & .39 & $-.38 * *$ & .21 & $-.21 * *$ \\
\hline $\begin{array}{l}\text { Membership in reli- } \\
\text { gious organization }\end{array}$ & .16 & $.11^{* *}$ & & & & & & & .40 & $.10^{* *}$ & .22 & $.11^{* *}$ \\
\hline $\begin{array}{l}\text { Participation in reli- } \\
\text { gious organization }\end{array}$ & & & & & .76 & $.17^{*}$ & & & & & & \\
\hline Ethnic self-definition & .16 & $.23 * *$ & .03 & $.17^{* *}$ & .75 & $.11^{* *}$ & & & .40 & $.37 * *$ & .22 & $-.31 * *$ \\
\hline Ethnic ceremonies & & & & & .74 & $-.10 *$ & .51 & $.18^{* *}$ & & & .21 & $.12^{*}$ \\
\hline Ethnic languages & .16 & $-.09 *$ & & & & & .52 & $.11^{*}$ & .39 & $-.08 *$ & .22 & $.16^{* *}$ \\
\hline Social embeddedness & .16 & $.16^{* *}$ & .03 & $.16^{* *}$ & & & & & .40 & $.24^{* *}$ & .23 & $.25^{* *}$ \\
\hline $\begin{array}{l}\text { Membership in eth- } \\
\text { nic organization }\end{array}$ & .16 & $.07 *$ & & & & & & & & & & \\
\hline $\begin{array}{l}\text { Participation in eth- } \\
\text { nic organization }\end{array}$ & & & & & .76 & $-.19 *$ & & & & & & \\
\hline
\end{tabular}

Differences in ethnic groups have significant effects on contact avoidance ( $p<$ .or), the avoidance of future spouses from a different religion $(\mathrm{p}<. \mathrm{oI})$, and support for residential segregation ( $\mathrm{p}<$.oI). Among Muslim respondents, the more they are affiliated with ethnic groups, the more they tend to avoid contact with Christians (eta $=.23$ ), the more they tend to avoid Christians as their future spouses (eta=.II), and the more they tend to support residential segregation (eta=.37). Participation in ethnic ceremonies is significantly related to the avoidance of a future spouse from a different religion (Muslims $\mathrm{p}<.05$ ). We identify that the more frequently Muslim respondents participate in ethnic ceremonies, the less they tend to avoid Christians as their future spouses ( $r=-$.Io). Differences in using ethnic languages have a significant effect on contact avoidance (Muslim $\mathrm{p}<.03$ ) and support for residential segregation (Muslims $\mathrm{p}<.05$ ). The more Muslim respondents speak their ethnic languages, the less they avoid contact with Christians $(\mathrm{r}=-.09)$, and the less they support residential segregation $(\mathrm{r}=-\mathrm{.08})$. Having friends from the same ethnicity is also significantly related to contact avoidance and support for residential segregation $(\mathrm{p}<$.oI). The ANOVA table shows that the more friends a Muslim respondent has with the same ethnic out-groups, the more they tend to avoid contact with Christians (eta=.I6), and the more they tend to support residential segregation (eta=.24). Also, differences between members and non-members in any ethnic organization are significantly related to contact avoidance. Here, we find that the more Muslim respondents become members or followers of any ethnic organization, the more they tend to avoid contact with Christians (eta=.07). In addition, participation in ethnic organizations has a significant effect on the avoidance of a future spouses from a different religion $(\mathrm{p}<.05)$. The more Muslim respondents participated in ethnic organizations, the less they avoid Christians as future spouses ( $\mathrm{r}=-$-.I9). 


\section{Christian respondents}

The following section describes the social location of intergroup contact avoidance among Christian respondents. Similar to Muslim respondents, attendance at rites of passage is significantly related to contact avoidance $(\mathrm{p}<$.or). The more Christian respondents participate in rites of passage, the more likely they are to avoid contact with Muslims (eta=.II). Moreover, religious practices relate significantly to contact avoidance $(\mathrm{p}<.05)$ and the avoidance of future spouses from a different religion $(\mathrm{p}=. \mathrm{oI})$. The more Christian respondents engage in religious practices, the more they avoid contact with Muslims ( $\mathrm{r}=.08$ ) and the more they avoid Muslims as their future spouses ( $\mathrm{r}=. \mathrm{I} 4)$. Having friends from the same religion is related to contact avoidance $(\mathrm{p}<$.oI) and support for residential segregation $(\mathrm{p}<. \mathrm{oI})$. Among Christian respondents, we find that the more Christian friends they have, the more they tend to avoid contact with Muslims (r=.I4), and the more they tend to support residential segregation $(r=.25)$. Having friends from different religions is also significantly associated with support for residential segregation ( $\mathrm{p}<$ .or). The more friends from different religions Christian respondents have, the less they tend to support residential segregation $(\mathrm{r}=.-2 \mathrm{I})$. Membership in any religious organization has a significant relation to support for residential segregation. The more Christian respondents become members and followers of any religious organizations, the more they tend to support residential segregation (eta=.II).

Among Christian respondents, differences in ethnic self-definition are significantly related to all measures of intergroup contact avoidance. The more they affiliate with their ethnic groups, the more they tend to support residential segregation (eta=.3I) and contact avoidance (eta=.II). Also, participation in ethnic ceremonies is significantly related to the avoidance of a future spouse from a different religion ( $\mathrm{p}<.05$ ), and support for residential segregation ( $\mathrm{p}<.05)$. The more frequently Christian respondents participate in ethnic ceremonies, the more they avoid Muslims as their future spouses (eta=.I8), and the more they tend to support residential segregation (eta=.I2). Use of ethnic languages is significantly related to the avoidance of a future spouse of a different religion $(\mathrm{p}<.05)$ and support for residential segregation $(\mathrm{p}<$.oI). The more often Christian respondents speak their ethnic languages, the more they avoid Muslims as their future spouses ( $\mathrm{r}=$.II), and the more they tend to support residential segregation (eta=.I6). Having friends from the same ethnicity is significantly related to contact avoidance and support for residential segregation. The more friends from the same ethnic groups Christian respondents have, the more they tend to avoid contact with Muslims (eta=.I6), and the more they tend to support residential segregation (eta=.25).

\section{CONCLUSION}

We acknowledge that several variables of ethno-religious identification, individual determinants, and intermediate variables are not comparable between Muslim and Christian respondents. The ANOVA table shows that the number of variables that have significant associations for Muslims and Christians are limited. Nevertheless, several variables of ethnoreligious identification are significant for both Muslim and Christian respondents. Contact avoidance, rites of passage, religious in-group, ethnic self-definition, and social embeddedness have significant relationships for both groups.

In the avoidance of future spouses from different religions, few variables have a significant relation for both Muslim and Christian respondents. Only ethnic self-definition and gender are significantly related to the avoidance of future spouses for both groups. Nevertheless, support for residential segregation has more variables that display significant associations for both groups. Religious in-group friends, religious out-group friends, membership in religious organizations, ethnic self-definition, ethnic languages, and social embeddedness are all significantly related to support for residential segregation in both groups. All intermediate variables are significantly related to support for residential segregation. 
Social identity theory holds that categorization, identification and comparison are likely to induce exclusionary reactions (Turner, I98I; Tajfel and Turner, I986; Gijsberts et al., 2004). We distinguished between ethno-religious selfdefinition, religious identification and ethnic identification. Findings from the regression analyses give evidence that ethno-religious self-definitions are significantly related to our dependent variables. Our hypothesis is confirmed when social categorization itself significantly relates to avoidance of intergroup contact.

\section{REFERENCES}

Abrams, D., \& Hogg, M.A. (1990). Social identification: A social psychology of intergroup relation and group processes. London and New York: Routledge.

Allport, G.W. (1954). The individual and his religion, a psychological interpretation. New York: The Macmillan Company.

Allport, G.W. (ig66). The religious context of prejudice. Journal for the Scientific Study of Religion, 5 (3), 447- 457.

Berger, P.L. (1967). The sacred canopy: Elements of a sociological theory of religion. Garden City: Doubleday \& Company, Inc.

Bilig, M.G., \& Tajfel, H. (1973). Social categorization and similarity in intergroup behaviour. European Journal of Social Psychology, 3, 27-52.

Brewer, M.B. (1999). The Psychology of prejudice: In-group love or out-group hate? Journal of Social Issues, 55 (3), 429-444.

Brewer, M.B. (200I). The many faces of social identity: Implications for political psychology. Political Psychology, 22 (I), II5-I25.

Coenders, M. (2001). Nationalistic attitudes and ethnic exclusionism in a comparative perspective: an empirical study toward the country and ethnic immigrants in 22 countries (Doctoral dissertation, Catholic University Nijmegen, 2001).

Durkheim, E. (1893/1933). The division of labour in society (G. Simpson, Trans.). New York: Macmillan.

Durkheim, E. (I993). The cultural logic of collective representation. In: C. Lamert (Ed.), Social theory, the multicultural and classic readings (pp. 89-99). Boulder, San Francisco, and Oxford: Westview Press.
Eisenstadt, S.N., \& Giessen, B. (1995). Power, trust, and meaning: Essays on sociological theory and analysis. Chicago: University of Chicago Press.

European Social Survey (ESS) (round 4 2008/9). (2008). Retrieved March I, 2015 from http:// www.europeansocialsurvey.org/docs/round4/ fieldwork/source/ESS4_source_main_questionnaire.pdf

Festinger, L. (1954). A theory of social comparison processes. Human Relations, 7 (2), II7-I40.

Gijsberts, M., Hagendoorn, L., \& Scheepers, P. (Eds.). (2004). Nationalism and exclusion of migrants: Cross national comparisons. Burlington, USA: ASHAGATE.

Greene, S. (I999). Understanding party identification: A social identity approach. Political Psychology, 20 (2), 393-403.

Hadiwitanto, H., Hermans, C.A.M., Sterkens, C.J.A., \& Machasin, M. (2007). Questionnaire on religion, conflict and trust in Indonesia: A comparative empirical study among Christian and Muslim Students (Unpublished questionnaire, December 2007).

Herring, M., Jankowski, T.B., \& Brown, R.E. (I999). Pro-Black doesn't mean anti-White: The structure of African-American group identity. The Journal of Politics, 6I (2), 363-386.

Jelen, T.G. (I993). The political consequences of religious group attitudes. The Journal of Politics, 55 (I), I78-I90.

LeVine, R.A., \& Campbel, D. T. (1972). Ethnocentrism: Theories of conflict, ethnic attitudes, and group behaviour. New York: John Wiley \& Sons.

Merton, R K. (I957). Social theory and social structure, Greencoe: Free Press.

Parsons, T. (I95I). The Social system, New York: Routledge \& Kegan Paul.

Phinney, J.S., \& Rotheram, M.J. (1987). Children ethnic socialization, pluralization and development. Beverly Hills, California: SAGE Publication.

Pitchford, S.R. (200I). Image-Making movements: Welsh nationalism and stereotype transformation. Sociological Perspectives, 44 (I), 45-65.

Rubin, M., \& Hewstone, M. (2004). Social identity, system justification, and social dominance: commentary on Reicher, Jost et al., and Sidanius et al. Political Psychology, 25 (6), 823-844.

Sanford, R.N. (1950/I969). Ethnocentrism in relation to some religious attitudes and practices. In: T. W. Adorno (Ed.), The authoritarian personality (pp. 208-22I). New York: W.W. Norton Company. 
Scheepers, P., Gijsberts, M., \& Hello, E. (2002a). Religiosity and prejudice against ethnic minorities in Europe: Cross-national tests on a controversial relationship. Review of Religious Research, 43 (3), 242-265.

Sterkens, C.J.A., \& Hadiwitanto, H. (20o9). From social to religious conflict in Ambon, an analysis of the origin of religious inspired violence. In: C. Sterkens, M. Machasin, \& F. Wijsen F. (Eds.). Religion, civil society and conflict in Indonesia. Nijmegen Studies in Development and Cultural Change 45 (pp. 59-86). Münster/ Berlin/Wien/London: Lit Verlag.

Sumner, W.G. (1906/I959). Folkways, a study of the sociological importance of usages, manners, customs, mores, and morals. New York: The New American Library.

Tabory, E. (I993). Avoidance and conflict: perceptions regarding contact between religious and Nonreligious Jewish youth in Israel. Journal for the Scientific Study of Religion, 32 (2), I48-I62.

Tajfel, H. (I970). Experiments in intergroup discriminination. Scientific American Journal, 23, 96-102.

Tajfel, H. (I978a). Interindividual behaviour and intergroup behaviour. In: H. Tajfel (Ed.), Differentiation between social groups: Studies in the social psychology of intergroup relations (pp. 27-6o). London, New York, San Francisco: European Association of Experimental Social Psychology \& Academic Press.

Tajfel, H. (I978b). Social categorization, social identity and social comparison. In: H. Tajfel (Ed.), Differentiation between social groups: Studies in the social psychology of intergroup relations (pp. 6I-76). London, New York, San Francisco: European Association of Experimental Social Psychology and Academic Press.

Tajfel, H. (I98I). Human groups and social categories, studies in social psychology. Cambridge: Cambridge University Press.

Tajfel, H., \& Turner, J. (I979/1986). An integrative theory of intergroup conflict. In: W.G. Austin \& S. Worchel (Eds.), The social psychology of intergroup relations (pp. I49-I78). Monterey, CA: Brooks/Cole.

Turner, J.C. (I978). Social comparison and social recognition: Two complementary process of identification. In: H. Tajfel (Ed.), Differentiation between social groups: Studies in the social psychology of Intergroup relations (pp. 25I-266). London, New York, San Francisco: European Association of Experimental Social psychology and Academic press.
Turner, J.C. (I98I). The experimental social psychology of intergroup behaviour. In: J.C. Turner \& H. Giles (Eds.), Intergroup Behaviour (pp. 66-Ior). Oxford: Blackwell.

Turner, J.C. (I999). Some current issues in research on social identity and self-categorization theories. In: N. Elopers, R. Spears, \& B. Doojse (Eds.), Social identity: Context, commitment, content (pp. 6-34). Oxford: Blackwell.

Turner, J.C., Hogg, M.A., Oakes, P.J., Reicher, S.D., \& Wetherell, M. (1987). Rediscovering the social group: A self-categorization theory. New York: Blackwell.

Tuti, S. (2008). Measurements for Indonesian survey (questionnaire for doctoral research in the department of Sociology, Radboud University Nijmegen).

Vertigans, S. (2007). Militant Islam and Weber's social closure: Interrelated secular and religious codes of exclusion. Journal Contemporary Islam, I (3), 303-32I.

Waterman, S., \& Kosmin, B.A. (I988). Residential patterns and processes: A study of Jews in three London Boroughs. Transactions of the Institute of British Geographers, I3 (I), 79-95.

Weber, M. (1930). The Protestant ethic and the spirit of capitalism, London: Allen \& Unwin.

Weber, M. (I978). Economy and society: An outline of interpretive sociology (G. Roth \& C. Wittich, Ed.). Berkeley: University of California.

Wolfe C.T., \& Spencer, S.J. (I996). Stereotypes and prejudice: Their overt and subtle influence in the classroom. American Behavioural Scientist, 40 (2), I76-I85. 